\title{
Yazılı Medyada Veganlığın ve Vejetaryenliğin Sunumu
}

\author{
Hasan Hüseyin Çakıcı \\ Anadolu Üniversitesi Sosyal Bilimler Enstitüsü \\ hh_cakici@anadolu.edu.tr \\ ORCID: 0000-0002-1085-7281 \\ Tezcan Özkan Kutlu (Dr. Öğr. Üyesi) \\ Anadolu Üniversitesi İletişim Bilimleri Fakültesi \\ tozkan@anadolu.edu.tr \\ ORCID: 0000-0001-9971-131X \\ Hakan Yılmaz (Doç. Dr.) \\ Anadolu Üniversitesi Turizm Fakültesi \\ hyilmaz5@anadolu.edu.tr \\ ORCID: 0000-0002-8512-2757
}

Başvuru Tarihi: 17.10.2019

Yayına Kabul Tarihi: 13.12.2019

Yayınlanma Tarihi: 24.01.2020

DOI: http://10.17680/erciyesiletisim.634287

\section{$\ddot{0 z z}$}

İnsanoğlunun doğup büyüdüğü coğrafya, içinde bulunduğu kültürel ortam, ailesi, yakın çevresi, mesleği vb. birçok faktör sahip olduğu yaşam biçimini etkilemektedir. Söz konusu yaşam biçimi içerisinde de beslenme alışkanlıkları önemli bir yere sahiptir. Toplum genelinde kabul edilen yaygın beslenme alıșkanlıklarının dıșında toplumsal azınlık denebilecek farklı gruplar tarafından tercih edilen vegan ve vejetaryen yaşam biçimleri ise son yıllarda oldukça ilgi görmektedir (Tunçay Son, 2016). Bu çalışmanın amacı 20002018 yılları arasında yayımlanmış gazete haberlerinde veganlığın ve vejetaryenliğin nasıl betimlendiğini ortaya koymaktır. Çalışma kapsamında 2000-2018 yıllarında yayımlanmış toplam 2161 haber metnine PRNet medya takip sistemi üzerinden ulaşılmıştır. Ulaşılan haberlere içerik analizi uygulanması amacıyla kodlama cetveli oluşturulmuş ve veriler SPSS paket programına girilerek içerik analizi uygulanmıştır. Araştırmada elde edilen bulgulara göre, 2000-2018 yılları arasında vegan ve vejetaryen konulu haberlerin sayısında önemli bir artış yaşandığı görülmektedir. Ancak yaygın medyada önemli bir yeri bulunan ulusal gazetelerdeki vegan ve vejetaryenlikle ilgili haberlere çoğunlukla haber ajansları ve köșe yazarlarının kaynaklık ettiği tespit edilmiştir. Konuyla ilgili yetkili ve uzman kișilerin görüşleri ise haberlerde çok az yer bulabilmiştir. Ayrıca gazetelerde haberler için ayrılan boyutların da küçük ve yetersiz olduğu saptanmıştır. Haber metinlerde veganlık ve vejetaryenliğin sürdürülebilir bir yaşam biçiminden ziyade daha çok alternatif beslenme ve bir diyet biçimi olarak çerçevelendiği görülmüştür.

Anahtar Kelimeler: Vegan, Vejetaryen, Medya, Temsil, İçerik Analizi. 
Research Article

\title{
The Presentation of Veganity and Vegetarian in Written Media
}

\author{
Hasan Hüseyin Çakıcı \\ Anadolu University Institute of Social Sciences \\ hh_cakici@anadolu.edu.tr \\ ORCID: 0000-0002-1085-7281 \\ Tezcan Özkan Kutlu (Asst. Prof. Dr.) \\ Anadolu University Faculty of Communication Sciences \\ tozkan@anadolu.edu.tr \\ ORCID: 0000-0001-9971-131X \\ Hakan Yilmaz (Assoc. Prof. Dr.) \\ Anadolu University Faculty of Tourism \\ hyilmaz5@anadolu.edu.tr
}

ORCID: 0000-0002-8512-2757

Date Received: 17.10 .2019

Date Accepted: 13.12.2019

Date Published: 24.01.2020

DOI: http://10.17680/erciyesiletisim.634287

\begin{abstract}
Geography where mankind was born and raised, the cultural environment, family, close environment, occupation, etc. many factors affect lifestyle. Also nutritional habits have an important place in this lifestyle. In addition to the widespread eating habits that are accepted throughout the society, vegan and vegetarian lifestyles preferred by different groups that can be called social minorities have received much attention in recent years (Tunçay Son, 2016). The aim of this study is to reveal how veganism and vegetarianism are described in newspaper articles published between 2000-2018. Within the scope of the study, 2161 news texts published in 2000-2018 were accessed via PRNet media monitoring system. In order to apply the content analysis to the news, a coding table was created and the data was entered into the SPSS package program and content analysis was applied. According to the findings of the research, it is seen that there has been a significant increase in the number of vegan and vegetarian news between 2000-2018. However, it was found that news agencies and columnists mostly source the vegan and vegetarian news in national newspapers, which have an important place in the mainstream media. On the other hand, the opinions of the authorized and expert persons on the subject were given little place in the news. In addition, the dimensions allocated for news coverage in the newspapers were found to be small and insufficient. In the news texts, veganism and vegetarianism are framed as an alternative nutrition and a diet rather than sustainable lifestyle.
\end{abstract}

Keywords: Vegan, Vegetarian, Media, Representation, Content Analysis. 


\section{Giriş}

Beslenme canlılık tarihi boyunca kaçınılmaz bir ihtiyaç olarak süregelmiştir. Diğer canlılardan farklı olarak düşünebilen insanoğlu çeşitli etmenlerden etkilenerek beslenme biçimini oluşturmaktadır. Beslenme biçimini etkileyen bu faktörler arasında insanın içinde bulunduğu kültürel, coğrafi, ekonomik, ekolojik yapı ve toplumun geçirdiği tarihsel süreç ilk sıralarda yer almaktadır (Sürücüoğlu ve Özçelik, 2008, s.1291). Bununla beraber insanoğlu kişisel tercih ve ideolojilerine göre özel beslenme biçimleri ortaya koyabilmektedir. Bu beslenme biçimlerinden biri olarak özellikle son ylllarda dikkatleri çeken vejetaryen ve vegan beslenmedir. Vejetaryen ve vegan beslenme günümüzde bilinirliği giderek artan beslenme yaklaşımlarındandır (Vatan ve Türkbaş, 2018, s.25).

Et ve et ürünleri yemek tercihlerinde etkili rol oynayan faktörlerdendir (Ruby vd., 2013, s.340). Konsantre protein ve yağ kaynağı olan et ve et ürünleri toplumların çoğu tarafından önemli bir besin maddesi olarak kabul edilirken (Fessler, ve Navarrete, 2003, s.6) bitkisel yiyeceklerden daha zararlı içerikler barındırması ve hayvanlara zarar vermemek adına et ve et ürünlerinin tüketilmemesi gerektiğini savunan yaklaşımlar da bulunmaktadır. Daha az et ve et ürünlerini tüketmeme yaklaşımlarının M.ö. 6.yy.'da civarında başladı̆̆ı bilinmektedir. Doğu dünyasında yaygın olan Hinduizm ve Budizm gibi dini inanışlar bitkisel ağırlıklı bir beslenme önermektedir. Batı dünyasında ise Yunanistan'da Pisagor ve Platon'un vejetaryen ilkeleri benimsediği bilinmektedir. Roma İmparatorluğunda bulunan Plutarhos ve Ovidius da insanların tarımsal ürünler yemesi gerektiğine yönelik yazmışlardır (Bedin vd., 2018, s.1). 1800'lü yıllardan itibaren et ve et ürünleri tüketilmemesi yaklaşımı sadece beslenme olarak algllanmayıp ahlaki ve dini boyutta tartışılarak et ve et ürünlerinin tüketilmemesine yeni bir anlam kazandırılmıștır (Whorton, 1994, s.1103).

Kökleri oldukça eskilere dayanan ve günümüzde oldukça ilgi ile karşılanan vejetaryenlik ve veganlık hakkında çeşitli çalışmalar olmasına karşın medyada nasıl yer bulduğuna yönelik çalışmaların sayısı azdır. Özellikle Türkiye'de vegan ve vejetaryen beslenenlere ilişkin yapılan çalışmalar çok az olmakla birlikte genellikle de sağlık ve beslenme ilişkisi çerçevesinde sınırlı kalmaktadır. Bu nedenle yürütülen bu çalışma ilgili literatüre katkı sağlaması ve veganlığın yazılı basında ne șekilde betimlendiğinin ortaya konulması bakımından önemli sayılmaktadır.

\section{Veganlık Nedir?}

Vejetaryen ve vegan kelimeleri Latince sağlıklı ve güçlü anlamlarına gelen vegatus'tan gelmektedir (Bedin vd., 2018, s.1). Vejetaryenlik hakkında çeşitli tanımlamalar mevcuttur ancak bunlar farklılıklar göstermektedir (Weinsier, 2000, s. 1211). Vejetaryen beslenme tiplerinde tüketilen gıdalardaki farklılıklar vejetaryen tanımının yapılmasını da zorlaştırmaktadır. Uluslararası Vejetaryen Bilirliğine (IVU, 2018) göre vejetaryenlik; bal, yumurta, süt ve süt ürünleri gibi hayvansal ürünlerin tercihe göre tüketildiği veya tüketilmediği tamamen bitkisel beslenme biçimine denilmektedir.

Shani ve DiPietro (2007, s.67) çalışmalarında vejetaryen beslenenleri nadiren vejetaryen, yarı vejetaryen, pesketaryen, lakto-ovo vejetaryen, lakto vejetaryen, vegan, çiğ beslenen (raw foodist) ve frutaryen olmak üzere sekiz grupta incelemiştir. Tunçay Son ve Bulut (2016) ise vejetaryenliği; semi-vejetaryenlik (flexitaryen), lacto-ovo vejetaryenlik, lacto vejetaryenlik, ovo vejetaryenlik, pesco-vejetaryenlik, polo-vejetaryen ve vegan olmak üzere yedi grupta ele almıştır. 
Türkiye Vegan Derneği'ne (TVD, 2019a) göre ise vejetaryen beslenme; vegan beslenme, lakto vejetaryen beslenmesi, ovo vejetaryen beslenmesi, lakto-ovo vejetaryen beslenmesi olmak üzere dört gruba ayrılmaktadır. Nadiren vejetaryenlik, flexitaryen, pesketaryen, polo-vejetaryen ve pesketaryen gibi vejetaryenlik tipleri Vegetarian Society (Ulusal İngiltere Vejetaryen Derneği, 2019) tarafından et tüketildiği gerekçesiyle vejetaryen olarak kabul edilmemektedir.

Tablo 1: Vejetaryen Tipleri

\begin{tabular}{|l|l|}
\hline Vejetaryen Tipleri & Diyet Özellikleri \\
\hline Nadiren vejetaryen & $\begin{array}{l}\text { Genellikle her türlü hayvansal besinleri tüketen ancak } \\
\text { nadiren de olsa vejetaryen beslenen kişilerdir. }\end{array}$ \\
\hline Flexitaryen & $\begin{array}{l}\text { Kırmızı et tüketiminden kaçınan beyaz et ve balık da dahil olmak } \\
\text { üzere yumurta ve süt gibi gıdaları da tüketen kişilerdir. }\end{array}$ \\
\hline Pesketaryen & $\begin{array}{l}\text { Süt, süt ürünleri ve balık eti tüketen diğer tüm } \\
\text { hayvansal gıdaları tüketmeyen kişilerdir. }\end{array}$ \\
\hline Polo-vejetaryen & Bitkisel besinlerin yanında sadece tavuk gibi kümes hayvanları tüketen kişilerdir. \\
\hline Lakto-ovo vejetaryen & Süt ve süt ürünleri tüketen diğer tüm hayvansal gıdalardan uzak duran kişilerdir. \\
\hline Lakto vejetaryen & Sadece süt ve süt ürünleri tüketen kişilerdir. \\
\hline Vegan & Bal dahil olmak üzere hiçbir hayvansal gıdayı tüketmeyen kişilerdir. \\
\hline Çiğ beslenen (Raw foodist) & $\begin{array}{l}\text { Yiyecekleri herhangi bir ısıl işleme tabi tutmadan ve } \\
\text { işlemeden yalnızca doğal haliyle tüketen veganlardır. }\end{array}$ \\
\hline Frutaryen & Yalnızca meyve olarak kabul gören yiyecekleri tüketen kişilerdir. \\
\hline
\end{tabular}

Kaynak: Shani ve DiPietro, 2007, s.67; Tuncay Son ve Bulut, 2016, s.831-832; TVD, $2019 a$.

Günümüzde popülerleşen vejetaryen beslenme biçimleri arasında en bilinenin vegan beslenme biçimi olduğu düşünülmektedir. The Vegan Society'nin (Vegan Derneği, 2019) yaptığı tanıma göre veganlık, hayvanların mümkün mertebede giyim ve kozmetik gibi nedenlerle maruz kaldığı zulmün her türlüsünden kaçınan ve aynı zamanda çevre ve hayvanlar için yararlı olan alternatiflerin geliştirilmesini ve bu alternatiflerin kullanımını destekleyen felsefe ve yaşam biçimidir. Daha açı bir ifadeyle veganlık herhangi bir şekilde hayvansal ürünlerin kullanımını tamamen reddetmektedir. Bu kapsamda bal, süt, yumurta, yoğurt, kefir gibi ürünler tüketilmemekle birlikte hayvansal yağ ve süt içeren çikolata, kek, pasta gibi ürünlerin de tüketilmesi söz konusu değildir. Vegan beslenenlerin diyetlerini yalnızca sebze, meyve, tahıl ve yemiş gibi ürünler oluşturmaktadır (Tunçay, 2016, s.52).

Bununla birlikte vegan olmak sanıldığı gibi sadece hayvansal besinleri tüketmemek değil aynı zamanda felsefesi de olan bir yaşam biçimidir (Greenebaum, 2015, s.130). Veganlık, veganizm olarak da adlandırılmaktadır. Veganizmin en temel prensibi hayvanların insanoğlunun kullanımı ve sömürüsü için var olmadıkları düşüncesidir. Veganizm hayvanlara zarar vermeyi reddeder (Kaçar, 2013, s.9-10). Hayvansal besinlerin yenilmediği gibi hayvanlardan elde edilen kürk, yün, ipek gibi malzemelerle hayvansal yağ içeren kozmetik ürünlerin de kullanılmamasını savunmaktadır (Vatan ve Türkbaş, 2018, s.26). Diğer bir ifadeyle, veganizm hayvanlara karşı saygllı olmayı benimseyen ve bu doğrultuda hayvansal olan hiçbir şeyin besin olarak tüketilmemesi gerektiğini savunurken aynı zamanda herhangi bir yolla hayvanlardan elde edilen giyim, kozmetik, temizlik ürünleri ile hayvanlar üzerinden yapılan sporları ve hayvanlara deneyler yapmayı da reddeden bir dünya görüşü olarak düşünülebilir. Bu bağlamda Mann'in de (2014) belirttiği gibi, veganlık bir beslenme ve diyet biçiminden çok daha fazlasıdır. 


\section{Bir Haber Konusu Olarak Medyada Veganlık}

Son birkaç yılda veganlık ve vejetaryenlikle ilgili haberlerin artışında özellikle sinema oyuncusu, şarkıcı, model gibi ünlü kişilerin bu beslenme biçimlerini tercih ettiklerini açıklamalarının etkisi olduğu söylenebilir (www.cnnturk.com, 2017). Popüler kültürün önemli aktörleri olarak bu ünlü kimliklerin medyadaki görünürlüklerinin sıradan kişilere kıyasla çok daha fazla olması medyadaki veganlık algısının biçimlenmesinde popüler kültürün etkisini arttırmaktadır. Örneğin geçtiğimiz Ocak ayında sosyal medya hesaplarından vegan olan takipçilerine ömür boyu geçerli olacak konser bileti hediye edeceğini duyuran dünyaca ünlü şarkıcı Beyonce (Bird, 2019) vegan beslenmeyle ilgili paylaşımlarıyla dikkat çeken popüler kültür aktörlerinden biri olmuştur.

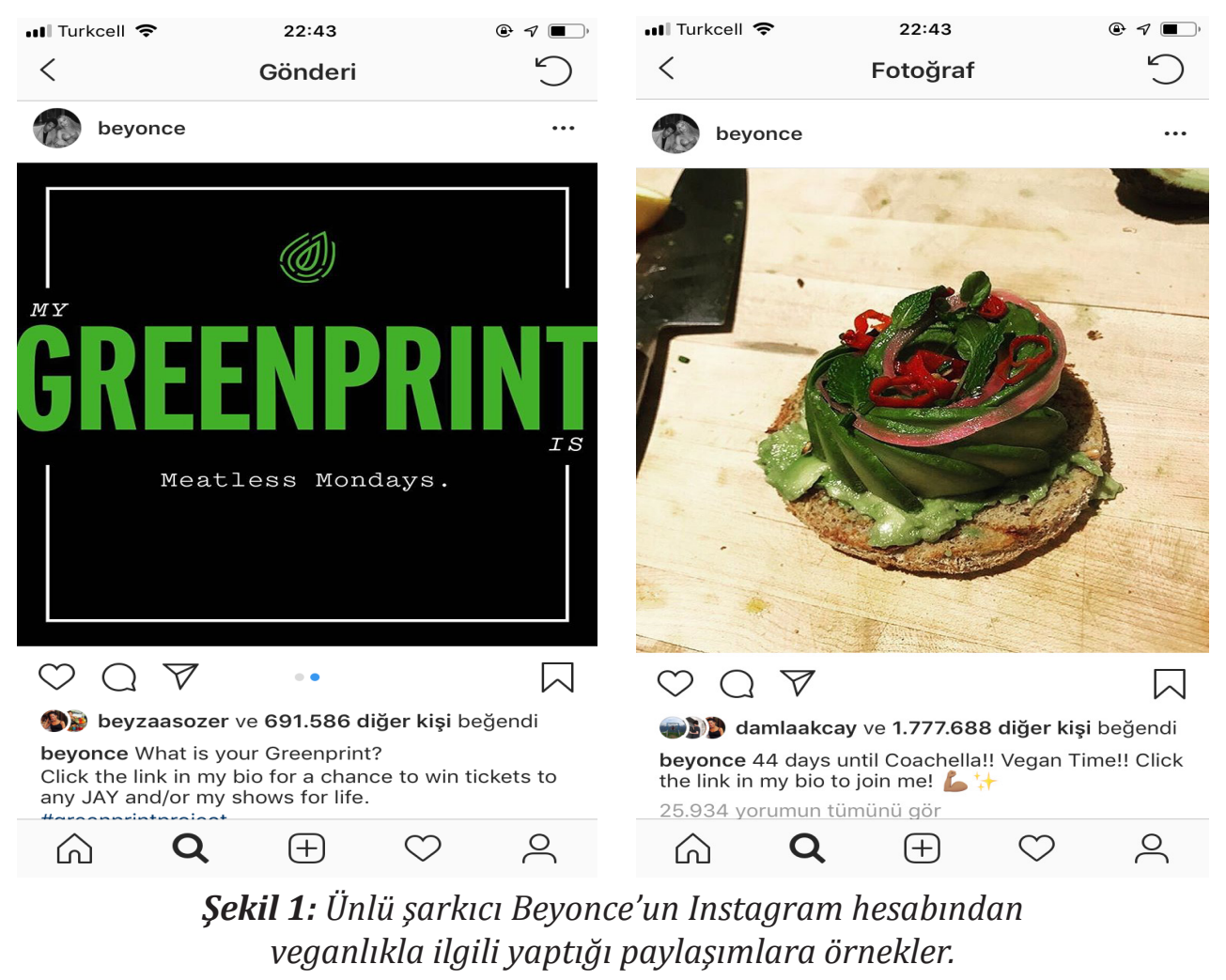

Bununla birlikte popüler kültürün en önemli aktarıcılarından biri olarak televizyon ve televizyon içerikleriyle mesajların kitleselleștirilmesinde etkili olan kanı önderlerinin söylemleri de medya gündemi üzerinde belirleyici olabilmektedir. Örneğin yakın bir zaman önce ulusal bir televizyon kanalındaki programda veganlıkla ilgili dile getirdiği sözlerle dikkatleri üzerine çeken İç Hastalıkları ve Kardiyoloji Uzmanı Prof. Dr. Canan Karatay'ın söylemleri medyada geniș bir yer bulmuștur (t24.com.tr, 2018). Öyle ki Türkiye Vegan Derneği Karatay'ın "Vegan demek tahıl beyinli demek..." șeklindeki ifadeleri hakkında suç duyurusunda bulunmuştur (www.cnnturk.com, 2018a).

Başka bir örnek olarak Türkiye'de popüler kültürün önemli sembollerinden olan ve özellikle sosyal medya üzerinden gerçekleștirdiği yardımseverlik faaliyetleriyle bilinen şarkıcı Haluk Levent'in "dini inancı nedeniyle vegan olamayacağı" yönündeki açıklamaları da büyük yankı uyandırmıştır. Haluk Levent Posta gazetesinden Alev Gürsoy Cimin'le yaptığı 5 Ağustos 2018 tarihli röportajda şunları dile getirmiştir (www.posta.com.tr, 2018): 
Aa, yoksa vegan misınız?

Hayır, vegan değilim çünkü inançlı bir adamım. İnançlı bir adam olmasaydım vegan olabilirdim. İnançlarımda Allah'ım bana kurban eti vermiş, Kurban Bayramı vermiş. Bunu yok sayamam.

\begin{abstract}
Aman veganlar duymasın!
Hiç fark etmez, duysunlar. Doğru gelmeyebilir kimilerine. Kurban etinin benim var oluşumla beraber geldiğini düşünüyorum. Ben inançlıyım ama hayvanların kesilme biçimi, mesela canlı canlı ıstakozun kaynatılması... Ben bunları yapmam. Ben inancıma göre kesilen kurban etini yerim. Büyük de konuşmayayım, ileride proteini başka türlü alabilirsek vegan da olabilirim, gelecekte et yemeyebilirim ama şimdi yiyorum.
\end{abstract}

Söz konusu röportaj "Haluk Levent: İnancım gereği vegan olamam...” başlığıyla farklı birçok medya kuruluşunun internet sitesinde de yayınlanmış ve sosyal medyada bolca paylaşılarak konuşulmuştur (www.cnnturk.com, 2018b; www.haberturk.com, 2018; http://www.milliyet.com.tr, 2018).

Dolayısıyla veganlığın, toplumun geneli tarafından yaygın olarak benimsenmiş beslenme biçimlerinden ayrılan nitelikleriyle alternatif bir beslenme ve yaşam tarzı olarak kabul edilmesinin birtakım dezavantajları da beraberinde getirdiğini söylemek mümkündür. Özellikle de toplumsal olarak belli bir azınlık tarafından benimsenmiş olan veganlıkla ilgili egemen söylemlerin "vegan olmayan çoğunluk" tarafından üretildiği görülmektedir. $\mathrm{Bu}$ nedenle de veganların kendi seslerini duyurabilmeleri ve veganlıkla ilgili egemen söylemlerin dişına çıkan alternatif söylemler üretebilmeleri son derece önemlidir. Bunu başarabilmenin en etkili yolu da kendi medyaları aracılığıyla kamuoyuna ulaşmaktır.

\title{
Vegan Medyasından Örnekler
}

Son yıllarda iletişim teknolojilerinde yaşanan devrimsel nitelikli gelişmeler geleneksel medya dünyasında da önemli değişiklikleri beraberinde getirmiştir. Kitle medyası olarak adlandırılan geleneksel iletişim araçlarının hakim olduğu yayıncılık dünyasının başlıca unsurlarını yerlerinden eden yeni bir aktör olarak internet tabanlı sosyal medyanın gücü bilinen kuralları yıkmıștır. Özellikle yeni medyadaki en önemli güç değişimi, pasif bir izlerkitlenin yerini aktif katılımcı bir kullanıcı kitlesinin almasıdır. Etkileșimliliği en üst düzeye çeken yeni iletişim olanakları kullanıcıların kendi medyalarını oluşturmalarına zemin yaratmıştır. Medya dünyasında içerik çeşitliliğinin hiç olmadığı kadar arttığı günümüz yeni medyasında birçok farklı konuda ilgi ve ihtiyaçlara hitap eden yeni yayıncılık biçimleri ortaya çıkmaktadır.

Bu bağlamda yeni yayıncılık olanakları özellikle kamusal temsiliyet açısından toplumun dezavantajlıları olarak bilinen kesimlerin kendi seslerini duyurmalarına firsat yaratmıştır. Toplumsal olarak azınlık sayılabilecek ve medyadaki temsiliyet açısından dezavantajlı kesimlerden biri olan vegan beslenenlere yönelik yayınlanan medya örneklerinden bazıları şunlardır:

https://gaiadergi.com/: Dijital yayınları internet üzerinden belli bir ücret karşılığı edinilebilen çevrimiçi (online) bir dergi olan Gaia aynı zamanda aynı adlı internet sitesi üzerinden de ücretsiz olarak içerik yayınlamaktadır. İnternet sayfasında vegan beslenme ve yaşamla ilgili birçok konuda içerikler paylaşan derginin yayın politikasına ilişkin şöyle bir bilgiye yer verilmektedir:

“Gaia Dergi; ırkçılığa, cinsiyet ayrımcılığına, türcülüğe ve betonlaşmaya karşı, doğadan ve doğaldan yana yaşamı savunan alternatif bir platformdur. Ekoloji, sürdürülebilir yaşam, yeşil felsefe, kadın hakları LGBTİ hakları, insan hakları, hayvan hakları, kültür-sanat, dünya kültürleri ve bilim-teknoloji alanında haberler ve röportajlar yapan görsel ve yazılı bir haber kaynağıdır." 
https://www.veganmedya.com: Bir topluluk bloğu şeklinde yayınlanan çevrimiçi içerik platformu olan Vegan Medya, internetin etkileşimlilik özelliğinden yararlanarak okuyucularının sayfalarında içerik paylaşmalarını desteklemektedir. Türkiye'deki veganları buluşturan bir platform olarak kendisini tanımlayan Vegan Medya'nın internet sayfasında "hakkında" kısmında şu sözlere yer verilmektedir:

\begin{abstract}
“Vegan Medya 1 Ekim 2018'de Türkiye'nin ilk içerik tabanlı vegan sosyal ağı olarak yayın hayatına başladı. Vegan olanlar için bir buluşma ve yeniliklerden haberdar olma platformu, vegan olmayanlar içinse; veganlığı daha iyi anlama, önyargılardan uzak yeni bir dünyayı keşfetme amacıyla kurulan bir sosyal medya platformu olmayı hedefledi. Veganlığa karşı olușturulan önyargıların kırılması, veganlığı anlatabilmek ve sömürünün olmadığı bir dünya düşünü, ilk önce sanal olarak hayata geçirmek amacıyla kullanıcılar, popüler haber, fotoğraf, galeri ve videolara tek bir noktadan ulaşırken aynı zamanda Vegan Medya'nın içeriğine de katkıda bulunabiliyor."
\end{abstract}

https://tvd.org.tr: İstanbul'da kurulan bir dernek olan Türkiye Vegan Derneği kendi internet sitesi üzerinden veganlıkla ilgili birçok konuda bilgilendirici içerikler yayınlamaktadır. Sitede yayınladıkları 28 maddelik manifesto ile derneğin veganlıkla ilgili politik ve etik olarak duruşu açıkça dile getirilmektedir. Etik, sağlık, beslenme ve çevre gibi konular vegan yaşam felsefesi açısından tartışılmaktadır. Bununla birlikte derneğin toplumsal bir farkındalık çalıșması olarak değerlendirebilecek bir proje olarak hataya geçirilen "Kirpi Sözlük (http://sozluk.tvd.org.tr)" uygulaması da hayvan haklarını kamusal söylem açısından ele alan bir girişim olarak dikkat çekmektedir. Kirpi Sözlük'ün "Hayvanları ezici ve aşağılayıcı türcü ifadelere, alternatif ifadeler geliştirme sözlüğü" (TVD, 2019b) olarak geliştirildiği belirtilirken, okuyucular da bu projeye destek olmaya davet edilmektedir:

"Bu platformda, hakkını savunamayan hayvan dostlarımızın hak etmedikleri benzetmelere ve sıfatlara maruz kalmamaları adına, sizler de rahatsızlık duyduğunuz ifadeleri paylaşıma açabilir, daha önce açılmış paylaşımlara görüş ve öneri bırakabilir ve oluşturmayı amaçladığımız bu kültürel temizlik hareketine katılımınızla destek verebilirsiniz."

\title{
Yöntem
}

Bu çalışmada ulusal çapta yayın yapan basılı gazetelerin (ve eklerinin) veganlıkla ilgili haberlere nasıl ve ne kadar yer verdiğini tespit etmek amacıyla içerik analizi yöntemi kullanılmıştır. Çalışma evrenini 2000 yılı ve sonrasında (2000-2018) yaygın basında basılıp dağıtılan tüm gazeteler ve bu gazetelere bağlı olarak gazete ekleri oluşturmaktadır. Çalışma evrenini oluşturan tüm haberler medya takip şirketi olan PRNet üzerinden elektronik ortamda elde edilmiştir. Bu yöntemin elle (manuel) taramaya göre daha pratik olması ve taranan anahtar kelimeler sayesinde konu ile ilgili hiçbir haberin atlanmaması gibi avantajları bulunmaktadır. Haberleri tespit etmek için yapılan dijital taramada "vegan", "veganizm" ve "vejetaryen" anahtar kelimeleri kullanılarak, 83 gazeteye ait toplam 2161 habere ulaşılmıştır. Ulaşılan 2161 haber 17.01.2019 tarihinde elektronik ortamda kayıt altına alınmıştır. Elde edilen haberler kodlama cetvelinden yararlanarak içerik analizine tabi tutulmuştur.

Çalışmanın amaçları doğrultusunda ilk olarak içerik analizi için kodlama cetveli hazırlanmıștır. Kodlama cetveli geliştirilirken literatür, ilgili haber içerikleri ve iletişim alanında uzman kişilerden görüş alınmıştır. Oluşturulan kodlama cetveli rastgele seçilen 50 haber üzerinden denenmiş ve çalışmanın amaçlarına hizmet ettiğine karar verilmiştir. Çalışma için hazırlanan kodlama cetvelinde 21 kategori bulunmaktadır. Bu kategoriler şunlardır: Araştırma birim numarası, anahtar kelime, tarih (gün), tarih (ay), yıl, yayım günü 
(haftanın günleri), gazete ismi, gazete tirajı, gazete ek bilgisi, haberin yayımlandığı sayfa, haberin konumu, haberin kapladığı alan, haberde görsel kullanımı, (görsel varsa) kullanılan görselin türü, (görsel varsa) görsel içerik uyumu, (görsel varsa) görselde kullanılan renk, haberdeki yazı fontu rengi, haberin zemininde kullanılan renk, içeriğin kategorileşmesi, haberin kaynağı ve (varsa) haberde bahsi geçen yemek ve yiyeceklerdir.

Çalışmanın amaç ve kapsamına uygun olması, kullanım kolaylığı sağlaması ve güvenilir olması nedeniyle kodlamalar SPSS 24.0 paket programı üzerinden gerçekleştirilmiştir. Kodlamalar SPSS paket programına 05.05.2019-31.07.2019 tarihleri arasında girilmiştir. Çalışmada toplanılan bazı verilerde kodlama cetvelinde yer alan "(varsa) haberde bahsi geçen yemek ve yiyecekler" kısmı için birden fazla cevap verildiği görülmüştür. Bu tür verilerde yer alan farklı yemek ve yiyecekler birden fazla sütun kullanılarak kodlanmış ve analiz sırasında farklı sütunlarda yer alınan bu veriler birleştirilmiştir.

\section{Bulgular ve Yorum}

Araştırmada 1356 gazete haberi ve 805 gazete eki haberi olmak üzere toplam 2161 habere ulaşılmıştır. Bu haberlerin 792'si vegan, 45'i veganizm, 883'ü vejetaryen ve 441'i de hem vegan hem de vejetaryen anahtar kelimelerinin geçtiği haberlerden oluşmaktadır. Elde edilen verilere göre bu haberlerin $\% 24,1^{\prime} i$ ayın 1 . günü ve 7 . günü arasında yer almaktadır. Haberlerin \%25,5’i, ayın 8. günü ve 15. günü arasında, \%25,9'u ayın 16. günü ve 23. günü arasında ve 24,5'i de ayın 24. günü ve 31. günü arasında yer almaktadır. $\mathrm{Bu}$ bağlamda haberlerin ay içerisinde eşit miktarlarda dağıldığı düşünülebilir.

Bununla birlikte Şekil 2'de de gösterildiği üzere 2000-2018 yılları arasında yayımlanmış olan vegan ve vejetaryen konulu haberlerin hafta sonu ağırlıklı olarak yayımlandığı bulgusuna ulaşılmıştır. Hafta sonu haber dağılımının daha fazla olmasında gazete eklerinin etkisi olduğu görülmüştür.

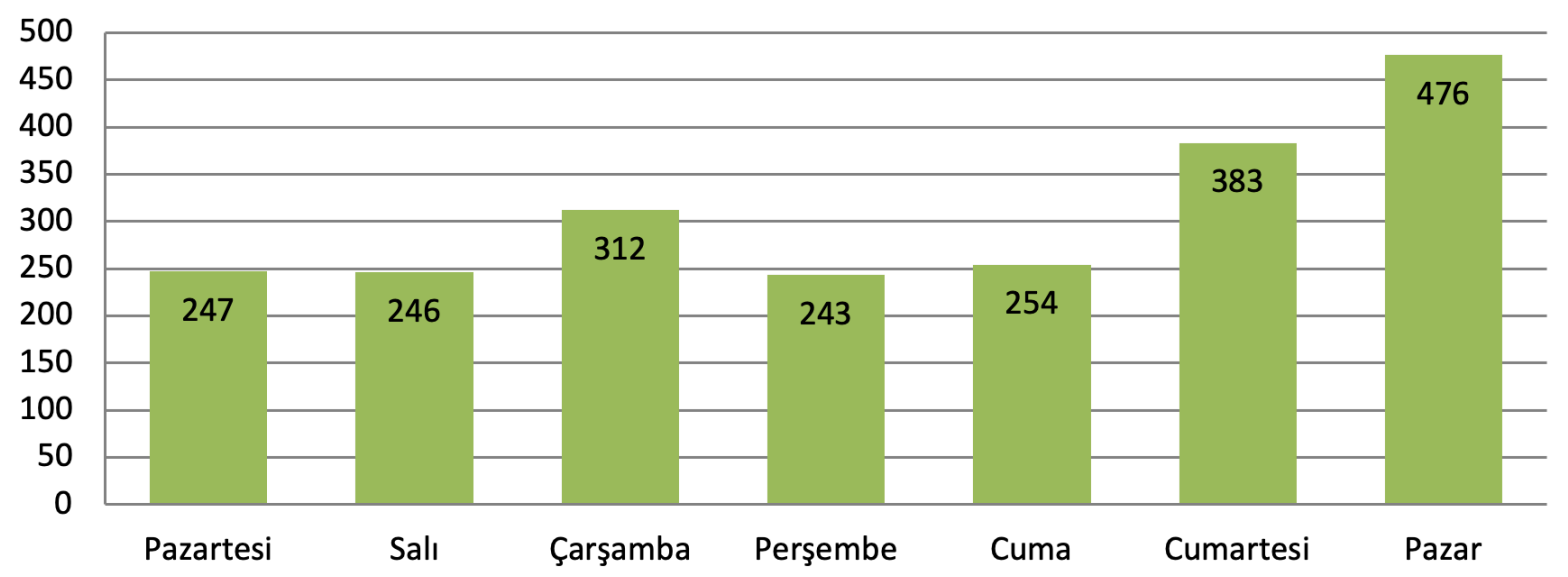

Şekil 2: Haberlerin günlere göre dağılımı

Araştırmada elde edilen bulgulardan haberlerin aylara göre dağılımına bakıldığında (Şekil 3) birkaç ay haricinde vegan ve vejetaryen konulu haber sayılarının birbirine yakın olduğu görülmektedir. Buna ilişkin olarak vegan ve vejetaryen konulu haberlerde Ağustos, Eylül ve Aralık aylarındaki düşüşe dair çeşitli yorumlarda bulunmak mümkündür. Bu durum; yaz sonu olan Ağustos ve Eylül aylarında evlerde kışa hazırlık için konserve, turşu, reçel yapımı gibi çeşitli saklama yöntemleri kullanılarak ürünlerin depolanmasıyla ilgili medyadaki haberlerin artması, Aralık ayı gibi kış mevsiminde ise tüketimin taze sebze ve meyvelerden ziyade tahıl ve kuru bakliyatlara kayması veganlıkla ilgili konulara talebi azaltmaktadır şeklinde yorumlanabilir. 


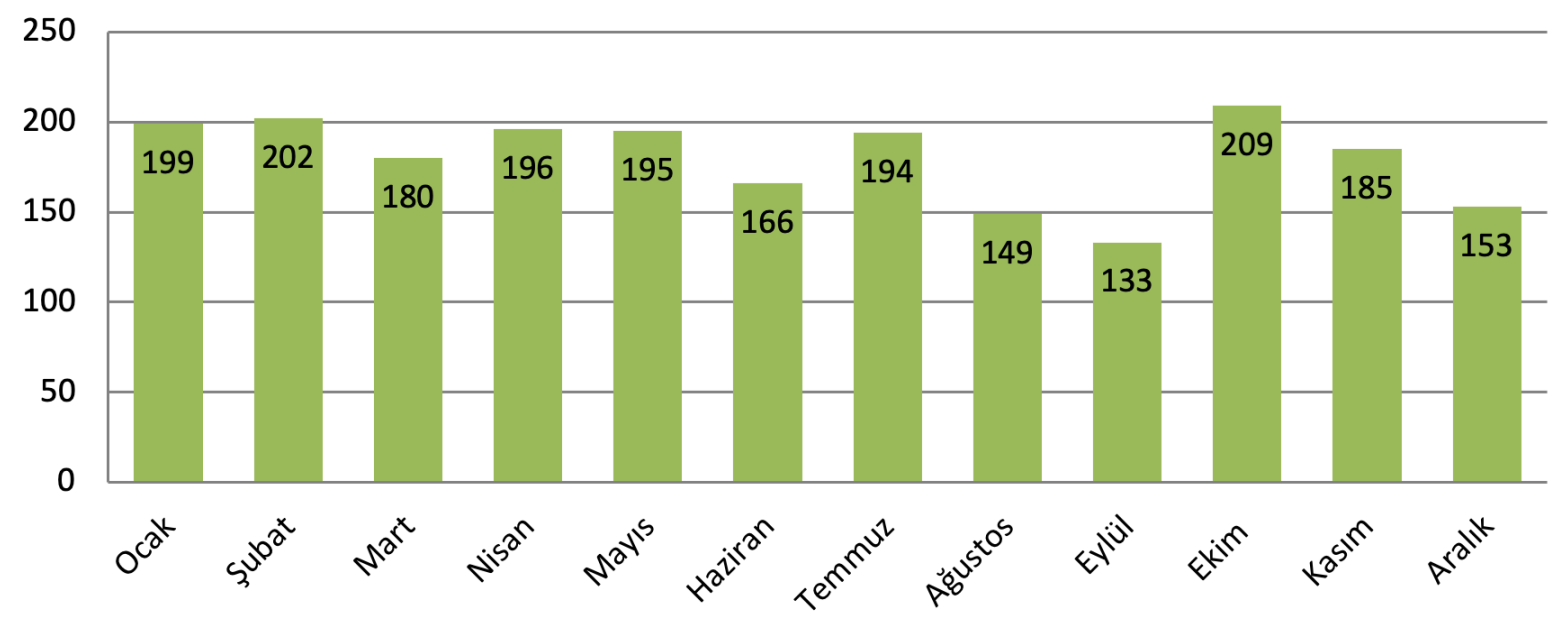

Şekil 3: Haberlerin aylara göre dağılımı

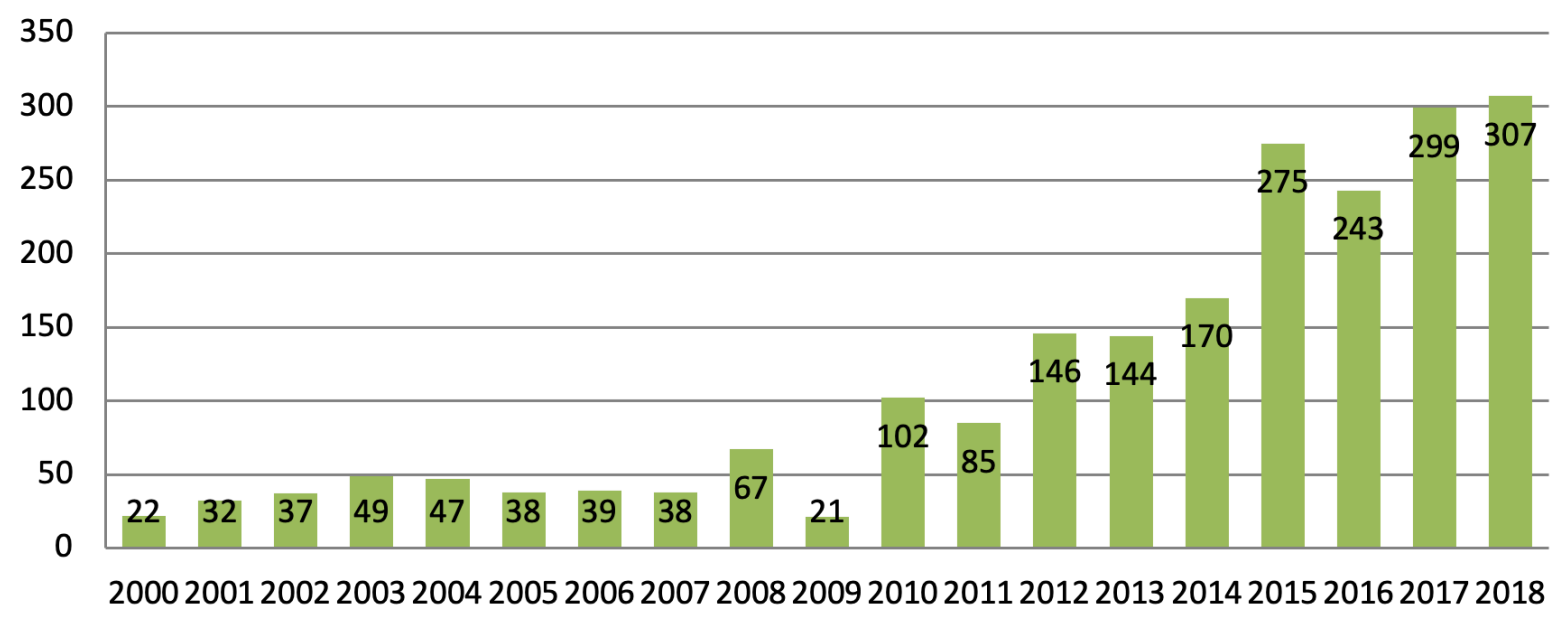

Şekil 4: Haberlerin yıllara göre dağılımı

Vegan ve vejetaryen konulu haberlerin yıllara göre dağılımına bakıldığında genel olarak 2000 yılından 2018 yılına kadar artış yaşandığı görülmektedir. Son yıllarda özellikle küresel ısınma ve iklim konusunda artan toplumsal hassasiyet, hayvan haklariyla ilgili gelişmeler, doğayı ve çevreyi korumaya yönelik geliştirilen sivil toplum çalışmalarının vegan ve vejetaryen yaşam tarzına ilgiyi arttırdığı düşünülebilir. Bu duruma bağlı olarak popülerleşen veganlık ve vejetaryenliğin de sayıları giderek artan vegan ve vejetaryen kişilerle birlikte toplumda daha fazla görünürlük kazandığı söylenebilir. Bu duruma örnek gösterebilecek haber metinlerine ait görsellere (Şekil 5) aşağıda yer verilmiștir. 


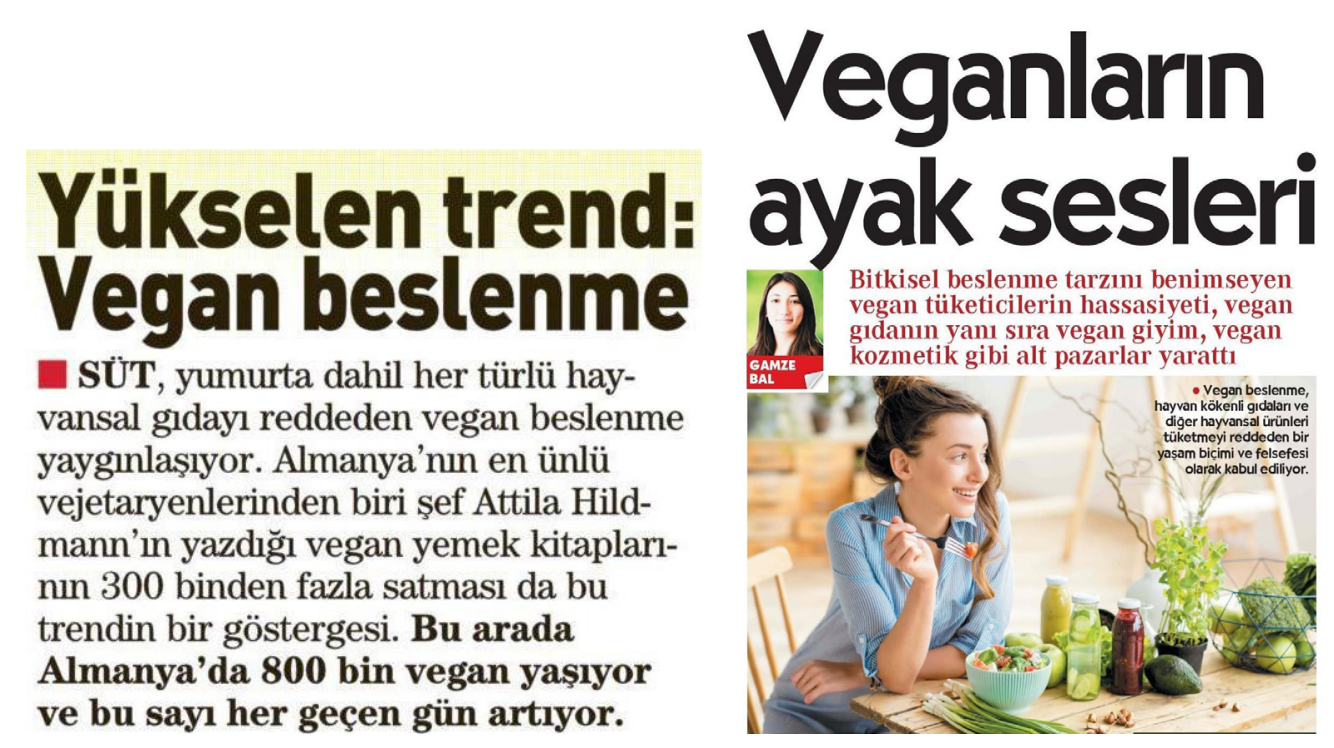

Şekil 5: Vegan ve vejetaryen yaşam tarzının arttı̆̆ına dair haber görselleri. Kaynak: Takvim (21.11.2013); Cumhuriyet (27.05.2018).

Haberlerin yayımlandıkları gazetelere göre dağılımına bakıldığında (Șekil 6); ilk sırada 194 (\%9) haber ile Sabah gazetesi yer alırken, onu 184 (\%8.5) haber ile Milliyet, 181 $(\% 8,4)$ haber ile Hürriyet, $149(\% 6,9)$ haber ile Haber Türk ve $106(\% 4,9)$ haber ile Birgün gazetesi takip etmektedir. Şekil 6'da gösterildiği gibi 11 gazeteye ait toplam 1294 $(\% 59,9)$ haber bulunmaktadır. Elde edilen bulgulara göre haberlerden 1189'u (\%56) tiraj olarak 100 bin barajını geçmektedir.

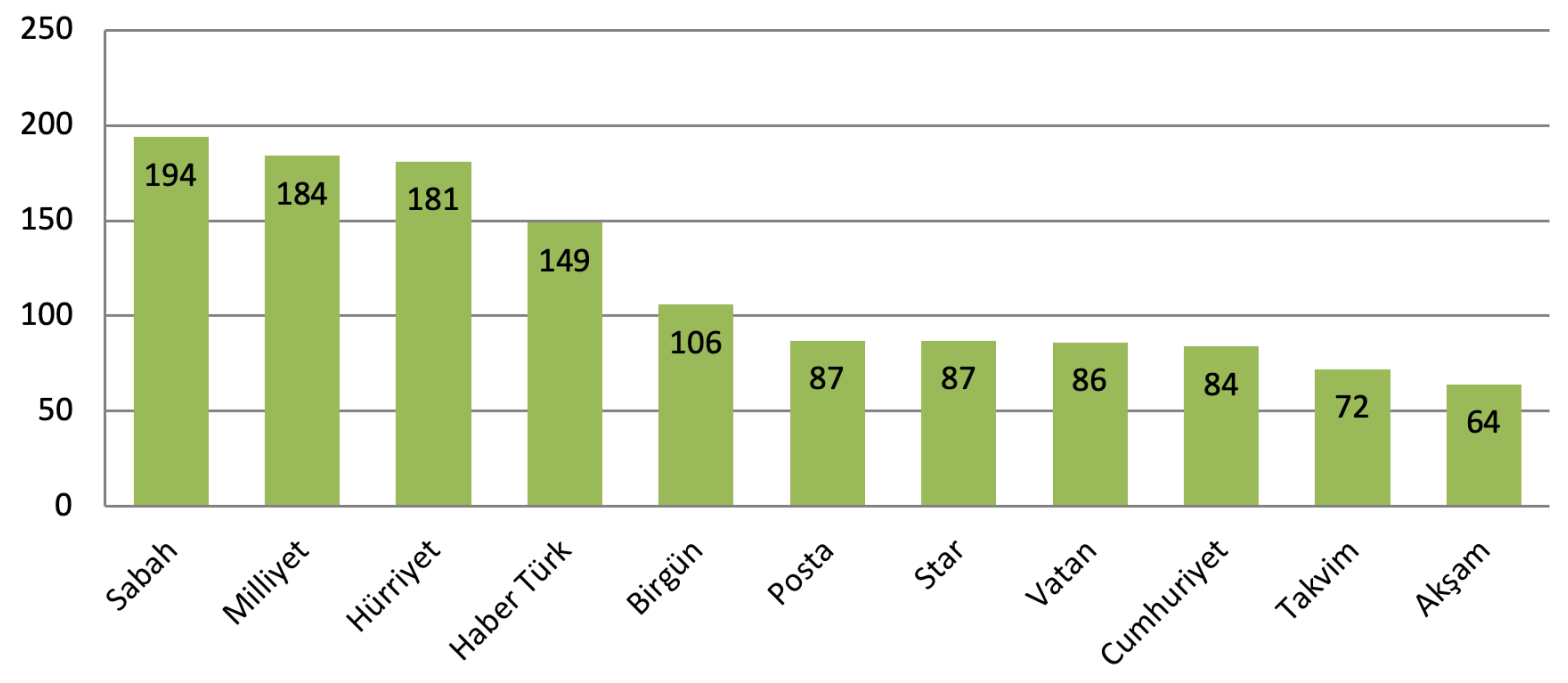

Şekil 6: Haberlerin gazetelere göre dağılımı

Haberlerin yer aldığı sayfalara bakıldığında ise anlamlı farklılıklar olmasından dolayı ana gazetelerde yer alan haberler ile gazete eklerindeki haberler arasında çapraz tablolama yoluna gidilmiştir. Haberlerin yayınlandıkları sayfalar ile sayfadaki konumlarını gösteren çapraz tablo verileri Tablo 2'de gösterilmiştir.

Tablo 2: Haberlerin yer aldığı sayfalar

\begin{tabular}{|l|c|c|c|c|c|}
\hline & Anasayfa & Sürmanşette geçiyor & Son sayfa & Diğer sayfalar & Toplam \\
\hline Gazete & $117(\% 8,6)$ & $8(\% 0,5)$ & $6(\% 0,5)$ & $1225(\% 90,4)$ & 1356 \\
\hline Gazete eki & $234(\% 29)$ & $2(\% 0,2)$ & $1(\% 0,2)$ & $568(\% 70,6)$ & 805 \\
\hline Toplam & $351(\% 16,2)$ & $10(\% 0,4)$ & $7(\% 0,3)$ & $1793(\% 83,1)$ & 2161 \\
\hline
\end{tabular}


Haberlerin yayınlandıkları sayfalardaki konumlarına bakıldığında; haberlerden 956 $(\% 44,2)$ haber sayfanın üst kısmında, 539 (\%24,9) haber sayfanın alt kismında, 485 haber sayfanın ortasında ve $181(\% 8,4)$ haber ise tüm sayfayı işgal edecek şekilde konumlandırıldığı görülmüştür.

Çalışmada haberlerin kapladıkları alanın büyüklüğü de incelenmiştir. Buna göre, haberlerden 1107 (\%51,2) haber 0-100 sütunXcm boyutuna sahiptir. Diğer bir ifadeyle, haberlerin yarısından fazlasının boyutu küçük ya da kutu haber denilen boyutlardadır. Diğer haberlere bakıldığında; 718 (\%33,2) haber 101-300 sütunXcm boyutunda, 132 $(\% 6,1)$ haber $301-400$ sütunXcm boyutunda ve $113(\% 5,1)$ haber ise 401 üzeri sütunXcm boyutlarına sahiptir. 2000-2002 yıllarına ait 91 (\%4,2) haberin boyut bilgileri PRNet üzerinde bulunmadığından bu haberler çıkartılarak analiz gerçekleștirilmiştir.

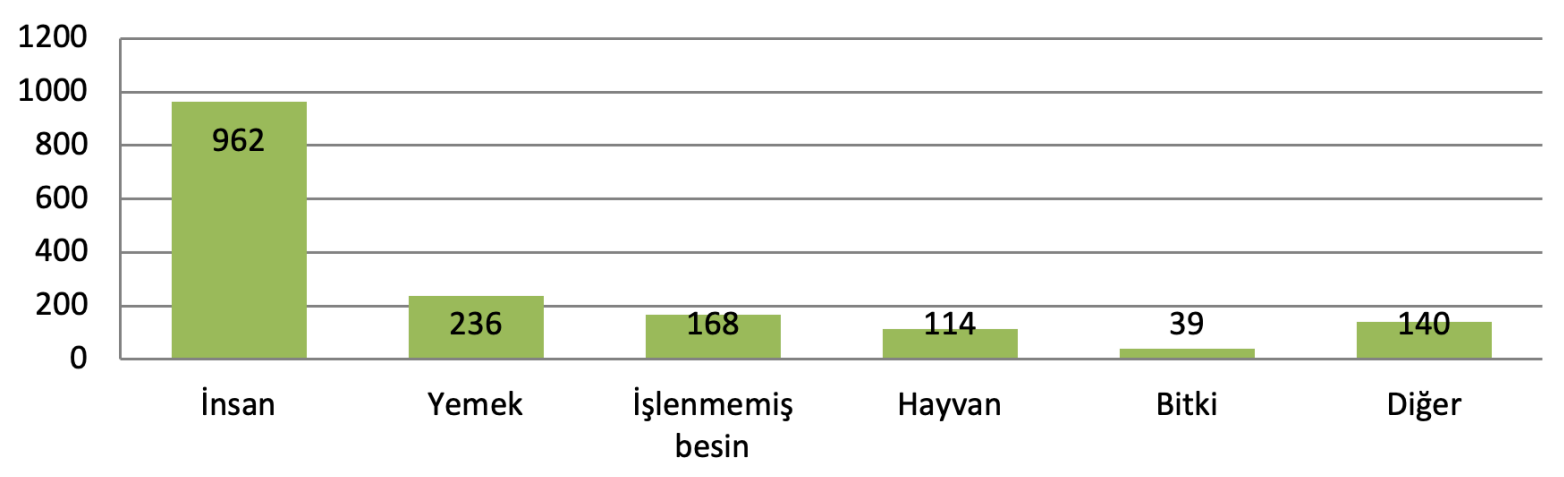

Şekil 7: Haberde kullanılan görseller

Çalışmada incelenen toplam 2161 haberden 502'sinde $(\% 23,2)$ görsel bulunmamaktadır. Görsel barındıran 1659 (\% 76,8) haberden 962'sinde (\%58) insan görseli kullanılmıştır. Görsellerde en az yer alan öge ise 39 (\%2,4) haber ile bitkilerdir (ağaç, fidan, çiçek vb.). Diğer görsellerde ise işletme, kitap, orman gibi çeşitli ögeler yer almaktadır. Görsel bulunan 1659 haber arasından sadece 26'sında (\%1,6) haber ile görsel birbirleriyle uyumlu görülmemiştir.

Görsellerde yer alan renklere bakıldığında ise $338(\% 20,4)$ haber ile yeşil rengi baskındır. Yeşil rengi; $231(\% 13,9)$ haber ile beyaz, 215 (\%13) haber ile siyah $190(\% 11,5)$ haber ile siyah-beyaz renk kullanımı takip etmektedir. En az kullanılan renk ise 100 (\%6) haber ile kahverengidir. Haberlerde kullanılan yazı fontu renklerine bakıldığında da; 2046 (\%94,7) haberin siyah fonta sahip olduğu görülmüștür. Yalnızca $5(\% 0,2)$ haberde yeşil renge sahip font kullanılmıştır. 1977 (\%91,5) haberde beyaz zemin kullanılırken, 30 (\%1,4) haberde ise yeşil zemin tercih edilmiştir. 


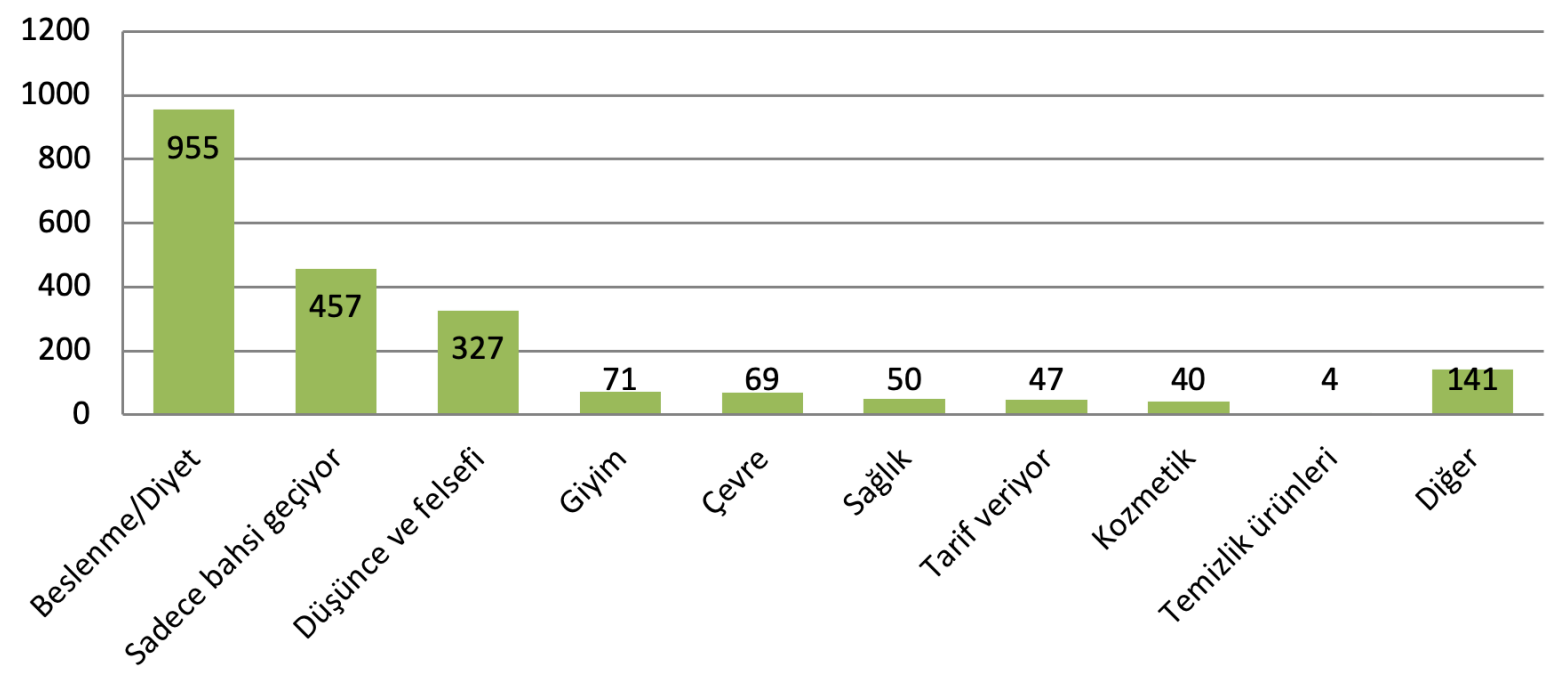

Şekil 8: Haberlerin içeriklerine göre dağılımı

Araștırmada, vegan ve vejetaryenlikle ilgili haberlerin büyük bir kısmının beslenme/ diyet konulu haberlerden oluştuğu görülmüştür. İkinci olarak anahtar kelimelerin sadece bahis konusu olarak geçtiği haberler takip etmektedir. Anahtar kelimelerin sadece bahis konusu olarak geçtiği haberlere şu haber örnek olarak gösterilebilir: "...Vejetaryen olan ve "Timber" adlı şarkısına çektiği klibinde bir hayli zayıflamış olduğu dikkat çeken şarkıcı 30 gün süreyle tedavi olacak." (HaberTürk, 2014). Üçüncü sırada ise hayvan hakları, yaşam biçimi ve aktivist davranışları gibi konuları barındıran düşünce ve felsefi olarak vegan ve vejetaryen konulu haberlerin takip ettiği görülmektedir.

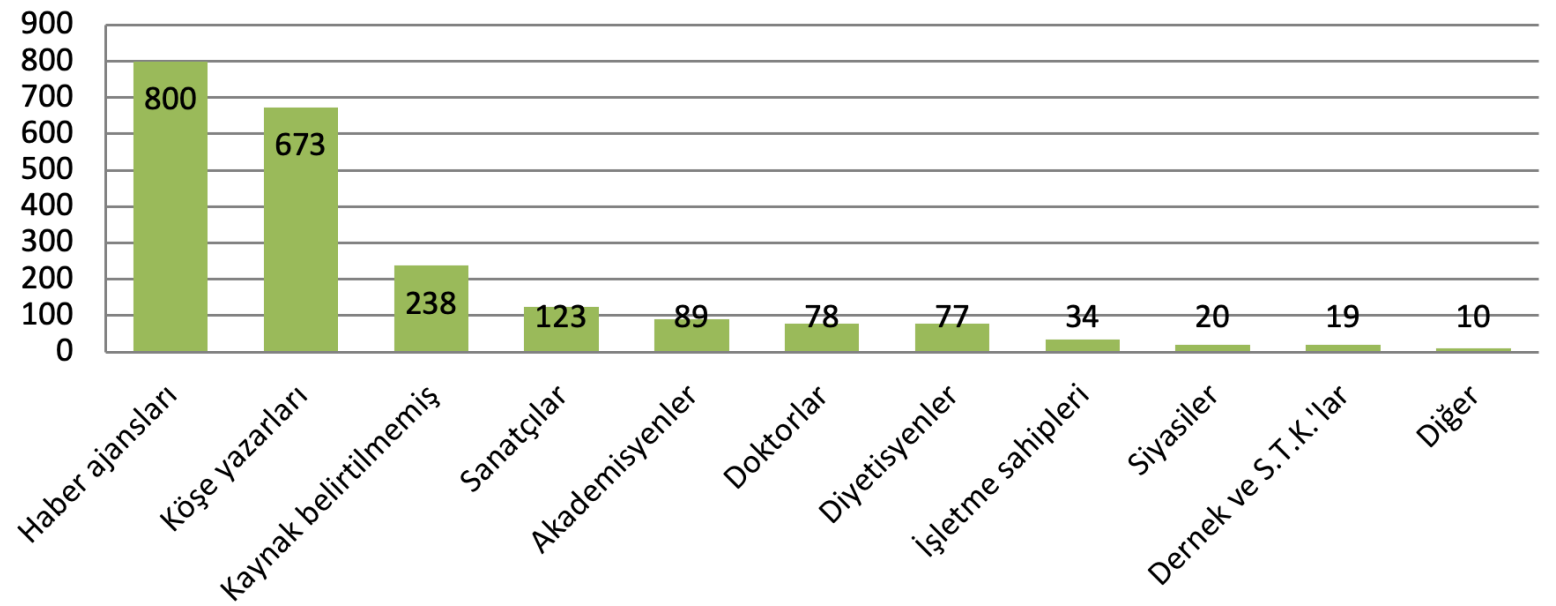

Şekil 9: Haberin kaynă̆ı

Vegan ve vejetaryen konulu haberlere en fazla 800 (\%37) haber ile haber ajansları kaynaklık etmektedir. Haber ajanslarını 673 (\%31,1) haber ile köșe yazarları takip etmektedir. Bu durum, vegan ve vejetaryen kişilerin kendileriyle ilgili haberlerde söz sahibi olamadıklarının göstergesi olarak yorumlanabilir. Daha önce çalışmanın kuramsal kısmında da belirtildiği üzere, toplumsal olarak belli bir azınlık tarafından benimsenmiş olan veganlık ve vejetaryenlikle ilgili egemen söylemlerin "vegan/vejetaryen olmayan çoğunluk" tarafından üretildiğini göstermektedir. 


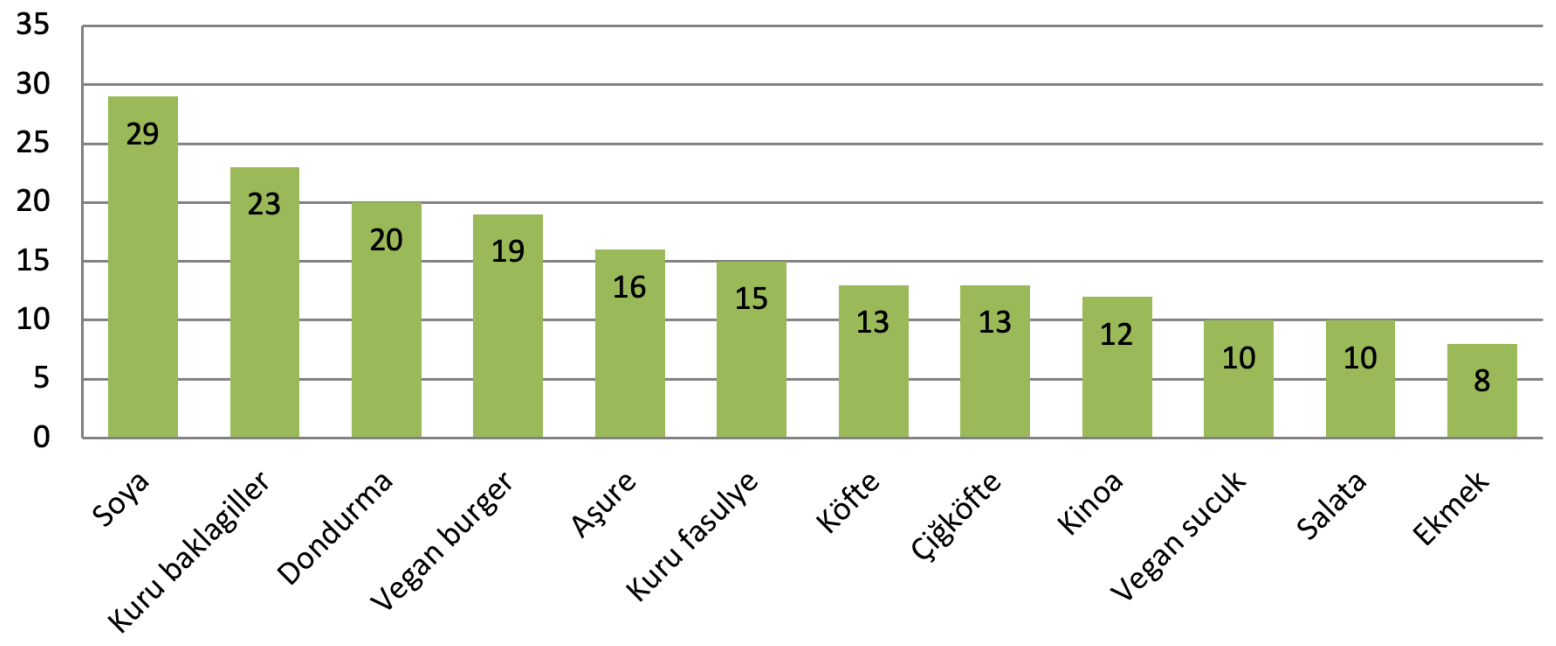

Şekil 10: Bahsi geçen yemek ve yiyecekler

Çalışmada incelenen 2161 haberden 1754'ünde $(\% 81,7)$ herhangi bir yemekten veya yiyecekten bahsedilmemiştir. Bu nedenle analizde yemekten veya yiyecekten bahseden 407 (\%18,3) haber ele alınmıştır. Ele alınan 407 haberde toplam 141 çeşit yemek ve yiyecek olmak üzere 471 kere yemekten ve yiyecekten bahsedilmiştir. Belirli yiyeceklerde yığılma görülmemiştir ve Şekil 10'da en fazla bahsi geçen yemek ve yiyecekler verilmiştir. Şekil 10'da yer verilen 12 yemek veya yiyecek $188(\% 39,9)$ kere bahsedilmiștir. En fazla bahsi geçen yiyecek ise $29(\% 6,1)$ haber ile soya fasulyesidir. Soya fasulyesini 23 $(\% 4,8)$ haber ile kuru baklagiller ve $20(\% 4,2)$ haber ile dondurma takip etmektedir. Soya fasulyesi ve kuru fasulye kuru baklagiller sınıfında olmasına rağmen başlı başına anlamlı bir değerde olması sebebiyle ayrı ayrı değerlendirilmiştir. Soya fasulyesinin haberlerde bu kadar ön planda olması, vegan/vejetaryen beslenenlerin soya fasulyesini tofu, bitkisel süt ve bitkisel kıyma (soya kıyması) gibi farklı şekillerde çokça tüketmeleriyle açıklanabilir.

\section{Sonuç}

Çalışmanın kapsamı doğrultusunda 2000-2018 yılları arasında "vegan”, "veganizm" ve "vejetaryen" anahtar kelimeleri taranarak toplamda 2161 habere ulaşılmıştır. Haberlerin dağılımlarında aylık olarak bir denge görülürken haftalık ve yıllık düzlemde farklılıklar saptanmiștır. Haftalık değerlendirme sonucunda hafta sonu vegan ve vejateryen haberlerin daha fazla olduğu, yıllık değerlendirmede ise her geçen yıl bu konulardaki haber miktarının arttığı sonucuna ulaşılmıştır. Dolayısıyla medya gündemi açısından veganlık ve vejetaryenliğin giderek artan oranda ilgi gördügünü söylemek mümkündür.

Vegan ve vejetaryenlikle ilgili haberlerin 955'i (\%44,2) gibi büyük çoğunluğu beslenme/ diyet konularını içerirken, diğer yandan da bu haberlerin birçoğunda herhangi bir yiyecekten bahsedilmediği görülmüştür. Bunun yanı sıra ilk yıllarda vegan ve vejetaryen beslenmenin kapsamı ve türlerini içeren haberler yer alırken son yıllarda daha çok yemeklerden bahsedilmiștir. Ayrıca kodlamalar sırasında beslenme konulu haberlerde vegan döner, vegan sucuk, vegan sosis, vegan hamburger köftesi, soya eti vb. yiyecekler ile etçil beslenmeye göndermeler olduğu görülmüştür. Bunlarla birlikte, beslenme ile ilgili olarak vegan ve vejetaryen beslenmenin sağlık açısından uygunluğu, demir ve B12 vitamin eksikliği gibi konulara da yer verilmiștir.

Vegan ve vejetaryen konulu haberlere çoğunlukla haber ajansları ve köşe yazarlarının kaynaklık ettiği ve gazetelerde haberler için ayrılan boyutların da küçük ve yetersiz olduğu 
saptanmıștır. Bu durum, yaygın yazılı medya aracı olan gazetelerde ilgili konunun fazla önemsenmediğini düşündürtmektedir. Dolayısıyla anaakım ya da yaygın medyadaki gazetelerin veganlık veya vejetaryenlikle ilgili bilgi almak isteyen kişilerin ihtiyaçlarına cevap vermediğini söylemek mümkündür. Bu nedenle vegan veya vejetaryen beslenmeyle ilgilenen kişiler; uzman akademisyenler, diyetisyenler ve doktorlar gibi bu konuda yetkin kişilerin açıklamalarına yer veren daha nitelikli içerik arayışlarına yönelmeye muhtaç bırakılmaktadır. Zaten yaygın medyada aradığını bulamayanların adresi çalışmada da vegan medyası başlığı altında söz edildiği gibi vegan/vejetaryen kişiler ya da dernekler tarafından yapılan yayınlar olmaktadır.

İncelenen gazetelerde 2000-2018 yıllarında en fazla bahsi geçen yemek ve yiyecekler arasında sirasiyla soya fasulyesi, kuru baklagiller (nohut, bakla, bezelye vb), dondurma (sorbeler), vegan burger, aşure, kuru fasulye, köfte, çiğköfte, kinoa, vegan sucuk, salatalar ve ekmek bulunmaktadır. Aslında vegan/vejetaryen olmayanların da temel gıda maddelerinden olan ekmek, sebze ve kuru baklagillerin vegan ve/veya vejetaryenlerin de beslenmelerinde önemli bir yer tuttuğu görülmektedir. Dolayısıyla genellikle farklı veya sıradışı olarak nitelendirilerek uygulanması çok zor bir beslenme şekli olarak etiketlenen vegan/vejetaryenliğin düşünüldüğü kadar zor olmadığını söylemek mümkündür.

\section{Kaynakça}

Bedin, E., Torricelli, C., Gigliano, S., De Leo, R., Pulvirenti, A. (2018). Vegan foods: Mimic meat products in the Italian market. International Journal of Gastronomy and Food Science, 13, 1-9.

Bird, N. (2019). Beyoncé and Jay Z's vegan food train is beckoning, are you hopping on. https://www.elle.com/uk/life-and-culture/a25731749/beyonce-and-jay-zsvegan-diet/ (Erişim: 04.05.2019).

Greenebaum, J. ( 2012). Veganism, identity and the quest for authenticity. Food, Culture \& Society, 15 (1), 129-144.

Fessler, D. ve Navarrete, C. (2003). Meat is good to taboo. Dietary proscriptions as a product of the interaction of psychological mechanisms and social processes. Journal of Cognition and Culture, 3 (2003), 1-40.

IVU. (2019, 4 Ocak). Definitions. https://ivu.org/definitions.html (Erişim: 4 Ocak 2019)

Kaçar, G. (2013). Vegan diyeti. İstanbul: Parşömen Yayınları.

Mann, S. E. (2014). More than just a diet: An inquiry into veganism. Anthropology Senior Theses. University of Pennsylvania. Erişim adresi: https://repository.upenn.edu/ cgi/viewcontent.cgi?article=1021\&context=anthro_seniortheses

Ruby, M. B., Heine, S. J., Kamble, S., Cheng, T. K., Waddar, M. (2003). Compassion and contamination. Cultural differences in vegetarianism. Appetite, 71 (1), 340-348.

Shani, A. ve DiPietro, R. B. (2007) Vegetarians: A typology for foodservice menu development, Hospitality Review, 25 (2), 64-73.

Sürücüoğlu, M. S. \& Özçelik, A. Ö. (2008). Türk mutfak ve beslenme kültürünün tarihsel gelişimi. Z. Dilek ve diğerleri (Ed.), 38. ICANAS-Uluslararası Asya ve Kuzey Afrika Çalışmaları Kongresi (s. 1289-1310) içinde. Ankara, Türkiye.

The Vegan Society. (2019). Definition of veganism. https://www.vegansociety.com/govegan/definition-veganism (Erişim: 04.01.2019). 
Tunçay, G. Y. (2016). Biyoetik yönüyle farklı bakış açlları ile veganlık. Journal of Current Researches on Health Sector, 6 (1), 51-62.

Tunçay Son, G. Y. ve Bulut, M. (2016). Yaşam tarzı olarak vegan ve vejetaryenlik, International Journal of Human Sciences, 13 (1), 830-843.

TVD. (2019a). Tanımlar. https://tvd.org.tr/2015/10/tanimlar/ (Erişim: 04.01.2019).

TVD. (2019b). Kirpi sözlük hakkında. https://tvd.org.tr/2017/12/kirpi-sozluk-hakkinda/ (Erişim: 31.07.2019).

Vatan, A. ve Türkbaş, S. (2018). Vejetaryen turist ve vegan turist kimdir?. Journal of Tourism and Gastronomy Studies, 6 (3), 24-39.

Vegetarian Society. (2019). What is a vegetarian?. https://www.vegsoc.org/definition (Erişim: 28.02.2019).

Weinsier, R. (2000). Use of the term vegetarian. American Journal of Clinical Nutrition, 71, 1211-1212.

Whorton, C, J. (1994). Historical development of vegetarianism. The American Journal of Clinical Nutrition, 59 (5), 1103-1109.

www.cnnturk.com. (2017). https://www.cnnturk.com/yasam/et-varsa-biz-yokuz-istevejeteryan-olan-unluler?page=1 (Erişim: 04.05.2019).

www.cnnturk.com. (2018a). https://www.cnnturk.com/turkiye/turkiye-vegan-dernegicanan-karatay-hakkinda-suc-duyurusunda-bulundu (Erişim: 04.05.2019).

www.cnnturk.com. (2018b). https://www.cnnturk.com/magazin/haluk-levent-inancimgeregi-vegan-olamam (Erişim: 04.05.2019).

www.haberturk.com. (2018). https://www.haberturk.com/haluk-levent-inancim-geregivegan-olamam-magazin-haberleri-2090470-magazin (Erişim: 04.05.2019).

http://www.milliyet.com.tr. (2018). http://www.milliyet.com.tr/cadde/haluk-leventinancim-geregi-vegan-olamam-2719249 (Erişim: 04.05.2019).

www.posta.com.tr. (2018). https://www.posta.com.tr/haluk-levent-inancim-geregivegan-olamam-allahim-bana-kurban-eti-vermis-2033807(Erişim:04.05.2019).

t24.com.tr. (2018). https://t24.com.tr/haber/canan-karatay-vegan-demek-tahil-beyinlidemek-veganlik-hastaliktir,731451 (Erişim: 04.05.2019). 


\title{
The Presentation of Veganity and Vegetarian in Written Media
}

\author{
Hasan Hüseyin Çakıcı \\ Tezcan Özkan Kutlu (Asst. Prof. Dr.) \\ Hakan Yılmaz (Assoc. Prof. Dr.)
}

\section{Extended Abstract}

Nutrition has been an inevitable need throughout vitality history. Mankind, who can think differently from other living things, is influenced by various factors and forms a diet. Among these factors affecting the way of nutrition are the cultural, geographical, economic, ecological structure and the historical process of the society in which people are involved (Sürücüoğlu and Özçelik, 2008, p.1291). Nevertheless, human beings are able to put forward nutritional forms according to their personal preferences and ideologies. One of these forms of nutrition is vegetarian and vegan nutrition which has attracted attention especially in recent years.

It is known that approaches to not consuming less meat and meat products started around the 6th century BC. Religious approaches such as Hinduism and Buddhism, which are common in the Eastern world, have suggested a vegetative diet. In the western world, it is known that Pythagoras and Plato in Greece adopted vegetarian principles. Plutarhos and Ovidius in the Roman Empire also wrote that people should eat agricultural products (Bedin et al., 2018, p.1). Since the 1800s, the approach of not consuming meat and meat products is not only perceived as a nutrition but has been given a new meaning by not considering meat and meat products in a moral and religious dimension (Whorton, 1994, p.1103). According to the International Vegetarian Awareness (IVU, 2018) vegetarianism; honey, eggs, milk and dairy products, such as the consumption of animal products are consumed or not consumed according to preference is called a purely vegetal diet. In the process from past to present, vegetarian forms such as vegetarian, flexitary, pesketarian, polo-vegetarian, lacto-ovo vegetarian, lacto vegetarian, vegan, raw foodist and frutarian have emerged.

According to the definition of the Vegan Society, veganism is a philosophy and way of life that avoids all kinds of persecution that animals are exposed to as much as possible due to clothing and cosmetics, but also supports the development and use of alternatives that are beneficial to the environment and animals. More specifically, veganism in any way completely rejects the use of animal products.

Although there are many studies about veganism and vegetarianism, the roots of which are very old and are very popular today, there are few studies about how they find their place in the media. In particular, studies on vegan and vegetarian fed ones in Turkey generally is limited but there is little agreement in the framework of health and nutrition. On the other hand, the news about veganism as an alternative form of nutrition, which is becoming more and more popular, has increased in the media today. Therefore, this study is considered important in terms of contributing to the related literature and revealing how veganism is described in the national press. The aim of this study is to reveal how veganism and vegetarianism are described in newspaper articles published between 2000-2018. Within the scope of the study, 2161 news texts published in 2000-2018 were accessed via PRNet media monitoring system. In order to apply the content analysis to 
the news, a coding table was created and the data was entered into the SPSS package program and content analysis was applied.

In line with the scope of the study, a total of 2161 news items were searched by searching the keywords taran vegan "," veganism "and" vegetarian arasinda between 2000-2018. While there was a monthly balance in the distribution of the news, differences were found on the weekly and annual levels. As a result of the weekly evaluation, it was concluded that there was more vegan and vegetarian news at the weekend and the annual amount of news on these issues increased each year. Therefore, it is possible to say that veganism and vegetarianism are getting more and more attention in terms of media agenda.

While 955 (44.2\%) of the news about vegan and vegetarianism were related to nutrition/ diet issues, it was seen that most of the news did not mention any food. In addition, in the early years, there were publications covering the scope and types of vegan and vegetarian nutrition, while more food was mentioned in recent years. In addition, during the encodings on nutrition news, vegan doner, vegan sausage, vegan sausage, vegan hamburger patties, soy meat and so on. food and carnivorous feeding. In addition to this, issues related to the health of vegan and vegetarian nutrition, iron and vitamin B12 deficiency were also included.

According to the findings of the research, news agencies and columnists mostly source the vegan and vegetarian news and the dimensions allocated for the news in the newspapers are small and insufficient. This makes us think that the issue is not given much importance in the newspapers, which are the national print media. Therefore, it is possible to say that national newspapers do not respond to the needs of people who want to get information about veganism or vegetarianism. Therefore, people interested in vegan or vegetarian diet; expert academicians, dietitians and physicians. The address of those who cannot find what they are looking for in the national media is the internet broadcasts made by vegan / vegetarian people or associations as mentioned in the study under the title of vegan media.

Among the most mentioned foods and foods mentioned in the newspapers examined in the years 2000-2018, soybeans, dried legumes (chickpeas, broad beans, peas, etc.), ice cream (sorbets), vegan burgers, asure, beans, meatballs, raw meat, quinoa, vegan sausage , salads and bread. In fact, it is seen that dried legumes, one of the main foodstuffs of nonvegan / non-vegetarians, are mainly consumed by vegan and / or vegetarians. Therefore, it is possible to say that vegan / vegetarianism, which is generally labeled as a different or unusual diet, is not as difficult as it is thought.

Keywords: Vegan, Vegetarian, Media, Representation, Content Analysis. 
